\title{
Metadherin contributes to epithelial-mesenchymal transition and paclitaxel resistance induced by acidic extracellular pH in nasopharyngeal carcinoma
}

\author{
CHANGYUN YU ${ }^{1}$, YONG LIU ${ }^{2}$ and ZHAOBING QIN ${ }^{1}$ \\ ${ }^{1}$ Department of Otolaryngology Head and Neck Surgery, The First Affiliated Hospital of Zhengzhou University, \\ Zhengzhou, Henan 450000; ${ }^{2}$ Department of Otolaryngology Head and Neck Surgery, Xiangya Hospital, \\ Central South University, Changsha, Hunan 410008, P.R. China
}

Received July 24, 2016; Accepted November 16, 2017

DOI: $10.3892 / \mathrm{ol} .2018 .7760$

\begin{abstract}
Paclitaxel resistance is a challenge to the treatment of nasopharyngeal carcinoma (NPC). An acidic extracellular $\mathrm{pH}\left(\mathrm{pH}_{\mathrm{e}}\right)$, a hallmark of solid tumors, is demonstrated to decrease the efficacy of chemotherapy. However, the precise function of acidic $\mathrm{pH}_{\mathrm{e}}$ in mediating chemotherapy in NPC remains unknown. In the present study, acidic $\mathrm{pH}_{\mathrm{e}}$ significantly decreased the cytotoxicity of paclitaxel in NPC cells. In addition, epithelial-mesenchymal transition (EMT)-like changes were observed in NPC cells cultured at acidic $\mathrm{pH}_{\mathrm{e}}$. Metadherin (MTDH), a novel oncogene, is expressed in multiple types of solid tumor, and is associated with several malignant cell characteristics, including malignant cell transformation, proliferation, angiogenesis, chemoresistance, invasion and metastasis. In the present study, MTDH expression was increased in NPC cells that had been cultured at an acidic $\mathrm{pH}_{\mathrm{e}}$. Furthermore, the silencing of MTDH expression reversed EMT molecular marker expression and sensitized NPC cells to paclitaxel. Taken together, the results of the present study provide evidence to support an association between acidic $\mathrm{pH}_{\mathrm{e}}$-induced paclitaxel resistance and MTDH-mediated EMT in NPC cells. Thus, targeting MTDH may provide a novel strategy for overcoming chemoresistance in NPC therapy.
\end{abstract}

\section{Introduction}

Paclitaxel is a cytotoxic agent that remains a first-line chemotherapy in the management of advanced nasopharyngeal

Correspondence to: Dr Changyun Yu, Department of Otolaryngology Head and Neck Surgery, The First Affiliated Hospital of Zhengzhou University, Zhengzhou, Henan 450000, P.R. China

E-mail: yuchangyun2007@163.com

Key words: nasopharyngeal carcinoma, metadherin, epithelialmesenchymal transition, acidic extracellular $\mathrm{pH}$, paclitaxel, drug resistance carcinoma (NPC) $(1,2)$. However, the development of intrinsic or acquired resistance limits the clinical efficacy of paclitaxel, which ultimately leads to tumor recurrence and a poor prognosis. Therefore, elucidation of the underlying molecular mechanisms that lead to paclitaxel resistance is an essential requirement to identify novel therapeutic strategies to overcome chemoresistance.

Extracellular $\mathrm{pH}\left(\mathrm{pH}_{\mathrm{e}}\right)$ is considerably more acidic in solid tumors compared with in normal tissue. Previous studies have identified that acidic $\mathrm{pH}_{\mathrm{e}}$ is an important characteristic of tumor tissues and is involved in cancer progression (3-7). Furthermore, acidic $\mathrm{pH}_{\mathrm{e}}$ has been reported to facilitate the development of resistance to chemotherapeutic drugs, including paclitaxel (8-10). Previous studies have provided evidence indicating that the 'ion-trapping' phenomenon mainly contributes to acidic $\mathrm{pH}_{\mathrm{e}}$-mediated drug resistance (11-13). However, paclitaxel is not ionizable and therefore the drug distribution should be unaffected by $\mathrm{pH}_{\mathrm{e}}$. Thus, it is important to understand the underlying molecular mechanisms responsible for the development of paclitaxel resistance.

Epithelial-mesenchymal transition (EMT) is a complex series of events, which was initially characterized as being essential during normal embryonic development (14). Previous studies have demonstrated that EMT is involved in physiological and pathological processes (15). Critically, previous studies have demonstrated an intricate association between chemoresistance and the changes associated with EMT (16). A previous study in ovarian cancer discovered that paclitaxel-resistant cells, which develop following continuous exposure to paclitaxel, exhibited the cellular and molecular characteristics of EMT (17).

Metadherin (MTDH), also known as astrocyte elevated gene-1 and lysine-rich carcinoembryonic antigen-related cell adhesion molecule-1-associated protein is an oncogene that is expressed in multiple tumors (18). Aberrant expression and dysfunction of MTDH is involved in tumor cell proliferation, survival and metastasis activity (19). Previous studies have confirmed that MTDH expression is associated with the chemoresistance of tumor cells by the regulation of a series of downstream target genes (20-24). The association between MTDH expression and EMT has been established in cervical 
cancer, breast cancer and hepatocarcinoma, which may contribute to chemoresistance (25-27).

In the present study, the influence of $\mathrm{pH}_{\mathrm{e}}$ on the cytotoxicity of paclitaxel in NPC cells in vitro was determined, and the associated mechanisms involved were investigated further. The results indicated that the cytotoxic efficacy of paclitaxel was markedly decreased at an acidic $\mathrm{pH}_{\mathrm{e}}$. Furthermore, it was revealed that MTDH-mediated EMT may confer acidic $\mathrm{pH}_{\mathrm{e}}$-induced paclitaxel resistance in NPC.

\section{Materials and methods}

Cell culture. The human NPC 5-8F cells were provided by the Cell Center of Central South University (Changsha, China). 5-8F cells were maintained as monolayer cultures in RPMI-1640 medium (Hyclone; GE healthcare, Chicago, IL, USA) supplemented with $10 \%$ fetal bovine serum, $100 \mathrm{IU} / \mathrm{ml}$ penicillin and $100 \mathrm{IU} / \mathrm{ml}$ streptomycin (all purchased from Gibco; Thermo Fisher Scientific, Inc., Waltham, MA, USA) at $37^{\circ} \mathrm{C}$ in a humidified atmosphere with $5 \% \mathrm{CO}_{2}$. Culture media with different $\mathrm{pH}$ values were prepared by the addition of $20 \mathrm{mM}$ 4-(2-hydroxyethyl)-1-piperazine-ethanesulfonic acid or $20 \mathrm{mM}$ 2-(N-morpholino)ethanesulfonic acid (both purchased from Thermo Fisher Scientific, Inc.) to RPMI-1640 medium and $\mathrm{pH}$ values were adjusted accordingly, using $\mathrm{NaOH}$ or $\mathrm{HCl}$ to $\mathrm{pH} 7.4$ or 6.8 , respectively. The actual $\mathrm{pH}$ in the media was determined prior to and following each experiment. Cells in the exponential growth phase were used for all subsequent experiments.

Paclitaxel cytotoxicity assays. The viability of NPC 5-8F cells was analyzed using a Cell Counting Kit-8 (CCK8; Beyotime Institute of Biotechnology, Shanghai, China) to produce cell viability curves according to the manufacturer's protocol. The $\mathrm{IC}_{30}$ value of paclitaxel in NPC 5-8F cells was confirmed as 2 . 947. $\mathrm{IC}_{30}$ is defined as the concentration of paclitaxel required to produce $30 \%$ inhibition of $5-8$ F cells. Subsequently, NPC $5-8 \mathrm{~F}$ cells were seeded at a density of $3 \times 10^{3}$ cells/well into 96-well plates in triplicate. Following $24 \mathrm{~h}$ of culture, the culture medium was aspirated and replaced with $100 \mu \mathrm{l}$ medium, buffered to $\mathrm{pH} 7.4$ or 6.8 , and supplemented with paclitaxel at its $\mathrm{IC}_{30}$ value. After $48 \mathrm{~h}$ of culture at $37^{\circ} \mathrm{C}$, the optical density values of each group were determined at a wavelength of $490 \mathrm{~nm}$. Each experiment was representative of three independent repeats.

Reverse transcription-quantitative polymerase chain reaction $(R T-q P C R)$. Total RNA was extracted using TRIzol reagent (Thermo Fisher Scientific, Inc., Waltham, MA, USA) according to the manufacturer's protocol. In total, $1 \mu \mathrm{g}$ RNA was used for reverse transcription to synthesize cDNA using the High Capacity RNA-to-cDNA Kit (Applied Biosystems; Thermo Fisher Scientific Inc.). In total, $20 \mu \mathrm{l}$ of reverse-transcription reaction components [10 $\mu 12 \mathrm{X}$ RT Buffer, $1 \mu 120 \mathrm{X}$ RT Enzyme mix, $7 \mu$ l Nuclease-free $\mathrm{H}_{2} \mathrm{O}$ (all from Applied Biosystems; Thermo Fisher Scientific, Inc.) and $2 \mu \mathrm{l} \mathrm{RNA]}$ were established and incubated for $60 \mathrm{~min}$ at $37^{\circ} \mathrm{C}, 5 \mathrm{~min}$ at $95^{\circ} \mathrm{C}$ and then incubated at $4^{\circ} \mathrm{C}$ for further investigation. $\mathrm{iQ}^{\mathrm{TM}} \mathrm{SYBR}^{\circledR}$ Green Supermix (Bio-Rad Laboratories, Inc., Hercules, CA, USA) was used to PCR amplification in a $20 \mu \mathrm{l}$ reaction system. The reaction system was prepared according to the following system: $10 \mu \mathrm{l} \mathrm{iQ}^{\mathrm{TM}} \mathrm{SYBR}^{\circledR}$ Green Supermix, $0.5 \mu \mathrm{l}$ PCR forward primer, 0. $5 \mu \mathrm{l}$ PCR reverse primer, $8 \mu \mathrm{l}$ Nuclease-free $\mathrm{H}_{2} \mathrm{O}$ (Bio-Rad Laboratories, Inc.) and $1 \mu \mathrm{l}$ cDNA template. Primer sequences used in the present study were as follows: E-cadherin forward, 5'-GCTGGACCGAGA GAGTTTCC-3' and reverse, 5'-CAAAATCCAAGCCCG TGGTG-3'; vimentin forward, 5'-TGTCCAAATCGATGT GGATGTTTC-3' and reverse, 5'-TTGTACCATTCTTCTGCC TCCTG-3'; N-cadherin forward, 5'-TGGGAAATGGAAACT TGATGGC-3' and reverse, 5'-AGTTGCTAAACTTCACTG AAAGGA-3'; MTDH forward, 5'-GATGATGAATGGTCT GGGTTAAA-3' and reverse, 5'-GACCTTTTGATCATCAGG AATTG-3'; GAPDH forward, 5'-GAGTCAACGGATTTG GTCGT-3' and reverse, 5'-TTGATTTTGGAGGGATCTCG-3'. PCR thermocycling conditions were as follows: $3 \mathrm{~min}$ at $95^{\circ} \mathrm{C}$ followed by 40 cycles of $15 \mathrm{sec}$ at $95^{\circ} \mathrm{C}$ and $30 \mathrm{sec}$ at $60^{\circ} \mathrm{C}$. The PCRs for each gene were performed in triplicate, and the mean values of fold changes were used to calculate mRNA expression. The fold change in expression of each gene was calculated using the $2^{-\Delta \Delta \mathrm{Cq}}$ method (28).

Western blot analysis. The western blot assay was performed as described previously $(29,30)$. In brief, the total protein $(50 \mu \mathrm{g})$ was separated by $10 \%$ SDS-PAGE and the separated proteins were transferred to polyvinylidene fluoride membranes (Millipore, Billerica, MA, USA). Membranes were blocked with $5 \%$ skimmed milk at room temperature for $1 \mathrm{~h}$, then incubated with the following primary antibodies at $4^{\circ} \mathrm{C}$ overnight: Primary antibodies used in the present study were: Mouse monoclonal antibody against E-cadherin (1:400; cat. no. sc-8426; Santa Cruz Biotechnology, Inc., Dallas, TX, USA), mouse monoclonal antibody against vimentin (1:200; cat. no. sc-32322; Santa Cruz Biotechnology, Inc.) and rabbit polyclonal antibody against MTDH (1:800; cat. no. 13860-1-AP, Proteintech Group, Inc., Chicago, USA). Subsequent to washing three times in TBST, membranes were incubated with horseradish peroxidase (HRP)-labeled goat Anti-mouse IgG $(\mathrm{H}+\mathrm{L}$; 1:1,000; cat. no. A0216) or HRP-labeled Goat Anti-rabbit IgG (H+L; 1:4,000; cat. no. A0208) (both purchased from Beyotime Institute of Biotechnology, Shanghai, China) for $1 \mathrm{~h}$ at room temperature. Bands were visualized using the BeyoECL Plus Detection System (Beyotime Institute of Biotechnology) and the images were obtained by X-ray film exposure. For normalization of protein loading, mouse monoclonal antibody against $\beta$-actin (1:1,000; cat. no. AF0003; Beyotime Institute of Biotechnology) was used. All antibodies were diluted using primary antibody dilution buffer or secondary antibody dilution buffer (both purchased from Beyotime Institute of Biotechnology). Each experiment was performed in triplicate.

Transient transfection. NPC 5-8F cells were transiently transfected with MTDH small interfering (si)RNA (cat. no. sc-77797) or control siRNA (cat. no. sc-37007; Santa Cruz Biotechnology, Inc.), according to the manufacturer's protocol. MTDH siRNA is a pool of three target-specific 19-25 nt siRNAs designed to knock down MTDH expression. Control siRNA is a non-targeting 20-25 nt siRNA designed as a negative control. $5-8 \mathrm{~F}$ cells $\left(2 \times 10^{5}\right.$ cells) were seeded on a six well plate $24 \mathrm{~h}$ prior to transfection. $8 \mu \mathrm{l}$ of siRNA duplex $(80 \mathrm{pM}$ 
siRNA) or control siRNA was diluted into $100 \mu 1$ siRNA transfection medium (cat. no. sc-36868; Santa Cruz Biotechnology, Inc., Dallas, TX, USA) as solution A. Furthermore, $6 \mu 1$ of siRNA transfection reagent (cat. no. sc-29528; Santa Cruz Biotechnology, Inc., Dallas, TX, USA) was diluted into $100 \mu \mathrm{l}$ siRNA transfection medium as solution B. Solution A and B were mixed and incubated for $45 \mathrm{~min}$ at room temperature. In total, $0.8 \mathrm{ml}$ siRNA transfection medium was added to each tube containing the siRNA transfection reagent mixture (solution $\mathrm{A}$ and $\mathrm{B}$ ), and overlayed onto the washed cells. Cells were incubated for $5-7 \mathrm{~h}$ at $37^{\circ} \mathrm{C}$ in a $5 \% \mathrm{CO}_{2}$ incubator. To determine the efficiency of the siRNA knockdown, the transfected cells were collected 3 days after transfection and the protein levels of MTDH were assessed using western blotting, as aforementioned.

Statistical analysis. All statistical analyses were conducted using SPSS 17. 0 software (SPSS, Inc., Chicago, IL, USA). Quantitative data are expressed as the mean \pm standard deviation. Statistical differences between groups were compared using two-tailed unpaired Student's t-tests. $\mathrm{P}<0.05$ was considered to indicate a statistically significant difference.

\section{Results}

Acidic $\mathrm{pH}_{e}$ decreases the cytotoxicity of paclitaxel in NPC cells. To confirm the association between acidic $\mathrm{pH}_{\mathrm{e}}$ and the sensitivity of NPC to paclitaxel, the $\mathrm{IC}_{30}$ value for paclitaxel in NPC 5-8F cells was confirmed as 2.947 (Fig. 1A). The viability of NPC 5-8F cells, incubated in normal ( $\mathrm{pH} 7.4$ ) or acidic (pH 6.8) medium, following paclitaxel stimulation at its $\mathrm{IC}_{30}$ for $48 \mathrm{~h}$, was evaluated using CCK- 8 assays. As presented in Fig. 1B, the survival rate of NPC 5-8F cells was $30.32 \pm 3.34$ compared with $45.58 \pm 6.34(\mathrm{P}<0.05)$, incubated in normal (pH 7.4) or acidic (pH 6.8) medium, respectively. These results indicated that acidic medium enhanced the survival rate of NPC 5-8F cells and that acidic $\mathrm{pH}_{\mathrm{e}}$ significantly decreased the cytotoxicity of paclitaxel in NPC cells.

EMT-like features of NPC cells grown in acidified medium. In order to investigate whether EMT is involved in acidic $\mathrm{pH}_{\mathrm{e}}$-induced paclitaxel resistance, the key markers of EMT were measured in NPC 5-8F cells grown in acidified medium for $48 \mathrm{~h}$. Phase-contrast microscopy revealed that NPC 5-8F cells cultured in acidic medium underwent several morphological changes, with some loss of adherence and cell-to-cell contact and the induction of a spindle-like form (Fig. 2A). The results of qPCR and western blot analysis demonstrated that expression of the characteristic mesenchymal markers vimentin and $\mathrm{N}$-cadherin were upregulated in NPC 5-8F cells cultured at $\mathrm{pH}_{\mathrm{e}}$ 6.8, compared with that of $\mathrm{pH}_{\mathrm{e}} 7.4$ (Fig. 2B and $\mathrm{C}$ ). In addition, a significant decrease in the expression of the epithelial maker E-cadherin was observed when NPC 5-8F cells were cultured in acidic medium (Fig. 2B and C). These results indicated that the acidic $\mathrm{pH}_{\mathrm{e}}$-induced paclitaxel-resistant NPC cells acquired the EMT phenotype.

Acidic $\mathrm{pH}_{e}$ enhances the expression of MTDH in NPC cells. In the present study, the potential molecular mechanism responsible for the EMT-like phenotypic changes in acidic

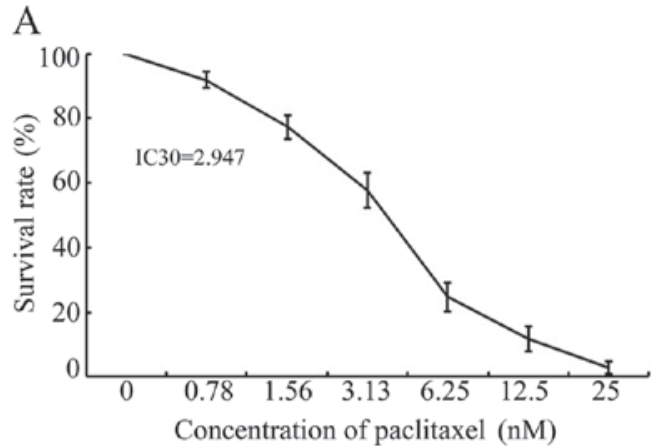

B

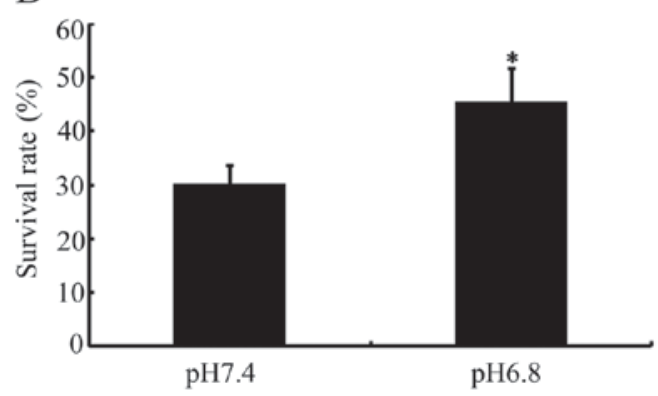

Figure 1. Influence of acidic $\mathrm{pH}_{\mathrm{e}}$ on the cytotoxicity of paclitaxel in NPC cells. (A) Determination of the $\mathrm{IC}_{30}$ value for paclitaxel in NPC 5-8F cells. (B) Cell viability was evaluated in NPC $5-8 \mathrm{~F}$ cells, incubated in normal ( $\mathrm{pH}$ 7.4) or acidic ( $\mathrm{pH}$ 6.8) medium, following paclitaxel stimulation at its $\mathrm{IC}_{30}$ value for 48 h. ${ }^{*} \mathrm{P}<0.05$ vs. $\mathrm{pH}$ 6.8. $\mathrm{pH}_{\mathrm{e}}$, extracellular $\mathrm{pH}$; NPC, nasopharyngeal carcinoma; $\mathrm{IC}_{30}$, concentration of paclitaxel required to produce $30 \%$ inhibition in NPC 5-8F cells

$\mathrm{pH}_{\mathrm{e}}$-induced paclitaxel resistance in NPC cells was explored. In a previous study, it was demonstrated that MTDH was increased and promoted EMT in squamous cell carcinoma of the head and neck (SCCHN) (30). Another previous report revealed that increased MTDH expression is also associated with drug resistance, including that of paclitaxel, in breast cancer, hepatocellular carcinoma and prostate cancer $(23,31)$. Therefore, the differences in MTDH expression in NPC cells cultured at a $\mathrm{pH}_{\mathrm{e}}$ of 6.8 compared with that at a $\mathrm{pH}_{\mathrm{e}}$ of 7.4 were investigated further. As presented in Fig. 3A, MTDH mRNA levels were increased when cultured in acidic medium. In addition, western blot analysis demonstrated that MTDH protein expression was significantly increased in response to an acidic culture environment (Fig. 3B). The results from the present study indicated that MTDH may be associated with an acidic $\mathrm{pH}_{\mathrm{e}}$-mediated EMT and paclitaxel resistance in NPC cells.

Silencing of MTDH reversed the EMT phenotype and sensitized NPC cells to paclitaxel in an acidic $\mathrm{pH}_{e}$ environment. To determine whether increased MTDH expression was associated with EMT in NPC cells, siRNA was used to downregulate MTDH expression in NPC cells cultured at a $\mathrm{pH}_{\mathrm{e}}$ of 6.8. Cells transfected with MTDH siRNA demonstrated decreased MTDH expression, accompanied by decreased vimentin expression and increased E-cadherin expression, compared with NPC 5-8F cells transfected with the control vector (Fig. 4A). The results demonstrated that E-cadherin downregulation and vimentin upregulation, induced by acidic $\mathrm{pH}_{\mathrm{e}}$ were attenuated by MTDH RNA interference in NPC 5-8F 
A

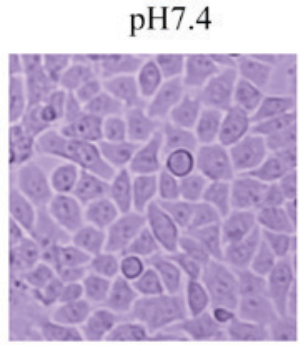

B

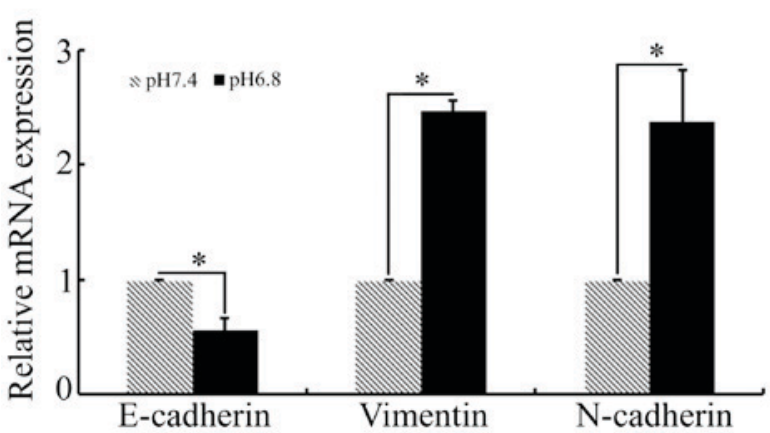

$\mathrm{C}$

pH6.8
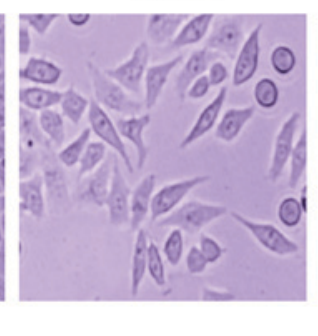

E-cadherin

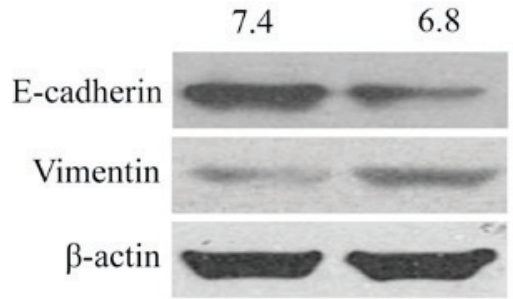

Figure 2. EMT-like changes are induced by acidity in NPC 5-8F cells. (A) Morphological changes induced by acidity in NPC 5-8F cells. Images captured at x100 magnification. (B) Reverse transcription-quantitative polymerase chain reaction and $(C)$ western blot analysis assessing the mRNA and protein levels of EMT makers. ${ }^{*} \mathrm{P}<0.05$ vs. $\mathrm{pH}$ 6.8. EMT, epithelial-mesenchymal transition; NPC, nasopharyngeal carcinoma.

cells. This is indicative of a crucial function for MTDH in the induction of the EMT phenotype in NPC cells, stimulated by an acidic $\mathrm{pH}_{\mathrm{e}}$ environment. Finally, the effects of inhibiting MTDH on the cytotoxicity of paclitaxel in NPC cells in acidic $\mathrm{pH}_{\mathrm{e}}$ environment were investigated. As presented in Fig. 4B, the cell survival rate of NPC 5-8F cells at an acidic $\mathrm{pH}_{\mathrm{e}}$ in the presence of paclitaxel at its $\mathrm{IC}_{30}$ was $45.92 \pm 6.3$, compared with $35.72 \pm 2.27$ in the MTDH-downregulated 5-8F cells $(\mathrm{P}<0.05)$. These results revealed that MTDH knockdown significantly restored the sensitivity of NPC 5-8F cells to paclitaxel, previously decreased in response to an acidic $\mathrm{pH}_{\mathrm{e}}$ environment.

\section{Discussion}

NPC is one of the most common malignant tumors in southern China and Southeast Asia, with $70 \%$ of newly diagnosed NPC cases, and thus is classified as locoregionally advanced disease (32). Paclitaxel is now routinely used to treat advanced NPC. However, the development of paclitaxel resistance is a significant barrier to the treatment of NPC. Therefore, elucidation of the molecular mechanisms underlying paclitaxel resistance is crucial to enhance the efficacy of treatment and to improve the survival rates of patients with NPC.

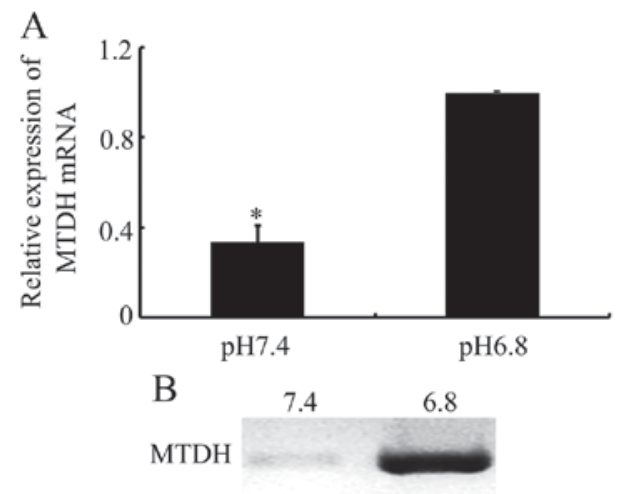

$\beta$-actin

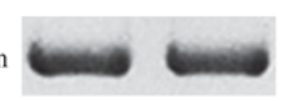

Figure 3. Acidic $\mathrm{pH}_{\mathrm{e}}$ enhances MTDH expression in NPC cells. (A) Reverse transcription-quantitative polymerase chain reaction and $(\mathrm{B})$ western blot analysis of the mRNA and protein levels of EMT in NPC 5-8F cells cultured at a $\mathrm{pH}_{\mathrm{e}}$ of 6.8 or 7.4 , respectively. ${ }^{*} \mathrm{P}<0.05$ vs. $\mathrm{pH} 6.8 . \mathrm{pH}_{\mathrm{e}}$, extracellular pH; MTDH, metadherin; EMT, epithelial-mesenchymal transition; NPC, nasopharyngeal carcinoma.

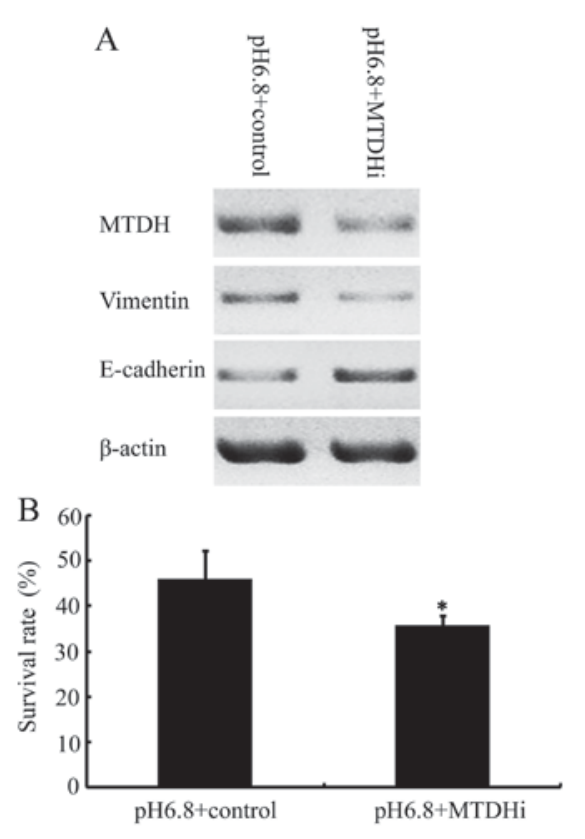

Figure 4. Silencing of MTDH reverses the EMT phenotype and sensitized NPC cells to paclitaxel in an acidic $\mathrm{pH}_{\mathrm{e}}$ environment. (A) Downregulation of E-cadherin and upregulation of vimentin induced by acidic $\mathrm{pH}_{\mathrm{e}}$ were attenuated by RNA interference with MTDH in NPC 5-8F cells. (B) MTDH knockdown significantly restored sensitivity of NPC 5-8F cells to paclitaxel. ${ }^{*} \mathrm{P}<0.05$ vs. pH 6.8 control. MTDH, metadherin; EMT, epithelial-mesenchymal transition; NPC, nasopharyngeal carcinoma; $\mathrm{pH}_{\mathrm{e}}$, extracellular $\mathrm{pH}$; MTDHi, metadherin interference; E-cadherin, epithelial cadherin.

Acidic $\mathrm{pH}_{\mathrm{e}}$, a hallmark of solid tumors, is thought to decrease the efficacy of chemotherapeutic regimens (33-35). However, the exact function of acidic $\mathrm{pH}_{\mathrm{e}}$ in mediating chemotherapeutic resistance in NPC remains unclear. In the present study, it was demonstrated that acidic $\mathrm{pH}_{\mathrm{e}}$ decreased the cytotoxicity of paclitaxel in NPC 5-8F cells in vitro. The results from the present study are consistent with those of a previous study that identified that acidic $\mathrm{pH}_{\mathrm{e}}$ leads to decreased paclitaxel sensitivity in murine EMT6 cells and the human bladder 
carcinoma cell line MGH-Ul (36). However, other previous in vitro studies have revealed no significant differences in the paclitaxel toxicity of MCF-7 cells cultured at a $\mathrm{pH}_{\mathrm{e}}$ of 6.8 compared with $7.4(12,13)$. The discrepancies in the results between distinct cancer cell lines indicated that the effects of acidic $\mathrm{pH}_{\mathrm{e}}$ on paclitaxel resistance may be cell line-specific.

Low $\mathrm{pH}_{\mathrm{e}}$ forms a physiological drug barrier, namely ion trapping, which has a negative effect on the efficacy of weakly basic chemotherapies, yet is more suited to weaker acidic therapeutics $(9,12)$. Previous studies have demonstrated that ion trapping mainly contributes to acidic $\mathrm{pH}_{\mathrm{e}}$-mediated chemoresistance. Owing to the complex structure of paclitaxel, which is composed of acidic and basic domains, the drug is not ionizable under physiological conditions, and thus its efficacy should be unaffected by ion trapping $(12,37)$. EMT is considered to be an essential feature of epithelial malignant tumor cells and is accompanied by increased vimentin and $\mathrm{N}$-cadherin expression, and decreased E-cadherin expression (38-40). Previous studies have revealed that acidic $\mathrm{pH}_{\mathrm{e}}$ induces EMT-like changes in human melanoma cells and Lewis lung carcinoma, which further promotes tumor progression $(41,42)$. In the present study, the transformation of fibroblast-like morphology, epithelial marker E-cadherin downregulation, and upregulation of mesenchymal markers vimentin and $\mathrm{N}$-cadherin, were observed in NPC 5-8F cells cultured at a $\mathrm{pH}_{\mathrm{e}}$ of 6.8 , suggesting that acidic $\mathrm{pH}_{\mathrm{e}}$ may induce EMT-like changes in NPC cells.

EMT is thought to be involved in wound healing, stem cell behavior, development and the progression of cancer. Emerging evidence has revealed a strong link between resistance to chemotherapy and the induction of EMT in cancer (43). A number of studies have indicated that chemoresistant cancer cells undergo morphological and molecular changes similar to EMT. In colorectal cancer, oxaliplatin-resistant cells acquired the ability to migrate and invade with phenotypic changes resembling those of EMT (44). In pancreatic and ovarian cancer, stable cell lines resistant to gemcitabine and paclitaxel established by continuous exposure were able to undergo EMT with increased Snail and Twist expression (17,45). A previous study also revealed that EMT is necessary for acquired resistance to cisplatin and increases the metastatic potential of NPC cells (46). In addition, another in vitro and in vivo study demonstrated that paclitaxel-resistant NPC cells exhibited characteristic EMT phenotypes, and forkhead box $\mathrm{C} 2$ promoted chemoresistance in NPC via the induction of EMT (47). Taken together, this evidence, together with the results of the present study supports the conclusion that EMT is responsible for acidic $\mathrm{pH}_{\mathrm{e}}$-induced paclitaxel resistance in NPC cells.

Previous results indicated that acidic $\mathrm{pH}_{\mathrm{e}}$ was able to promote tumor progression through the increase in the expression of specific genes, including those encoding vascular endothelial growth factor, interleukin- 8 and matrix metalloproteinase-9 (48-51). MTDH, a novel oncogene, is prevalently expressed in numerous solid tumors, including SCCHN, and is involved in multiple cellular behaviors associated with malignant cells, including malignant cell transformation, proliferation, angiogenesis, invasion and metastasis (30,52-55). There is further evidence to indicate that MTDH modulates the sensitivity of cancer cells to chemotherapeutic agents $(20,56)$. In the present study, the results demonstrated that MTDH expression was significantly enhanced in NPC cells cultured in an acidic medium. In a previous study, our group identified that MTDH promoted EMT in SCCHN (30). In the present study, the potential function of MTDH in acidic $\mathrm{pH}_{\mathrm{e}}$-mediated EMT was investigated further. The data demonstrated that knockdown of MTDH abrogated the acidic $\mathrm{pH}_{\mathrm{e}}$-induced suppression of E-cadherin and increased vimentin expression in NPC 5-8F cells; which indicated that MTDH is involved in acidic $\mathrm{pH}_{\mathrm{e}}$-mediated EMT-like changes in NPC cells. Furthermore, the cytotoxicity of paclitaxel in NPC cells recovered, whereas MTDH was knocked down, under acidic conditions. Taken together, these results supported the existence of an association between acidic $\mathrm{pH}_{\mathrm{e}}$-induced paclitaxel resistance and MTDH upregulation-mediated EMT in NPC cells.

In conclusion, the results of the present study indicated that MTDH-mediated EMT may be an alternative mechanism through which acidic $\mathrm{pH}_{\mathrm{e}}$ promotes paclitaxel resistance in NPC. Thus, normalization of $\mathrm{pH}_{\mathrm{e}}$ may be a reasonable strategy for tumor therapy. Furthermore, targeting MTDH may provide a novel strategy for overcoming chemoresistance in NPC therapy. However, further in vivo experiments are required to confirm whether MTDH is a viable target for therapy.

\section{Acknowledgements}

The present study was funded by the National Natural Science Foundation of China (grant no. 81402232).

\section{References}

1. Leong SS, Wee J, Tay MH, Toh CK, Tan SB, Thng CH, Foo KF, Lim WT, Tan T and Tan EH: Paclitaxel, carboplatin, and gemcitabine in metastatic nasopharyngeal carcinoma: A Phase II trial using a triplet combination. Cancer 103: 569-575, 2005.

2. Leong SS, Wee J, Rajan S, Toh CK, Lim WT, Hee SW, Tay MH, Poon D and Tan EH: Triplet combination of gemcitabine, paclitaxel, and carboplatin followed by maintenance 5-fluorouracil and folinic acid in patients with metastatic nasopharyngeal carcinoma. Cancer 113: 1332-1337, 2008.

3. Vaupel P, Kallinowski F and Okunieff P: Blood flow, oxygen and nutrient supply, and metabolic microenvironment of human tumors: A review. Cancer Res 49: 6449-6465, 1989.

4. Gatenby RA and Gillies RJ: A microenvironmental model of carcinogenesis. Nat Rev Cancer 8: 56-61, 2008.

5. Fang JS, Gillies RD and Gatenby RA: Adaptation to hypoxia and acidosis in carcinogenesis and tumor progression. Semin Cancer Biol 18: 330-337, 2008.

6. Hashim AI, Zhang X, Wojtkowiak JW, Martinez GV and Gillies RJ: Imaging $\mathrm{pH}$ and metastasis. NMR Biomed 24: 582-591, 2011.

7. Peppicelli S, Bianchini F and Calorini L: Extracellular acidity, a 'reappreciated' trait of tumor environment driving malignancy: Perspectives in diagnosis and therapy. Cancer Metastasis Rev 33: 823-832, 2014.

8. Raghunand $\mathrm{N}$ and Gillies RJ: $\mathrm{pH}$ and drug resistance in tumors. Drug Resist Updat 3: 39-47, 2000.

9. Wojtkowiak JW, Verduzco D, Schramm KJ and Gillies RJ: Drug resistance and cellular adaptation to tumor acidic $\mathrm{pH}$ microenvironment. Mol Pharm 8: 2032-2038, 2011.

10. Trédan O, Galmarini CM, Patel K and Tannock IF: Drug resistance and the solid tumor microenvironment. J Natl Cancer Inst 99: 1441-1454, 2007.

11. Parks SK, Chiche J and Pouysségur J: Disrupting proton dynamics and energy metabolism for cancer therapy. Nat Rev Cancer 13: 611-623, 2013.

12. Mahoney BP, Raghunand N, Baggett B and Gillies RJ: Tumor acidity, ion trapping and chemotherapeutics. I. Acid pH affects the distribution of chemotherapeutic agents in vitro. Biochem Pharmacol 66: 1207-1218, 2003. 
13. Raghunand N, Mahoney BP and Gillies RJ: Tumor acidity, ion trapping and chemotherapeutics. II. pH-dependent partition coefficients predict importance of ion trapping on pharmacokinetics of weakly basic chemotherapeutic agents. Biochem Pharmacol 66: 1219-1229, 2003.

14. Thiery JP: Epithelial-mesenchymal transitions in development and pathologies. Curr Opin Cell Biol 15: 740-746, 2003.

15. Thiery JP, Acloque H, Huang RY and Nieto MA: Epithelial-mesenchymal transitions in development and disease. Cell 139: 871-890, 2009.

16. Wang Z, Li Y, Ahmad A, Azmi AS, Kong D, Banerjee S and Sarkar FH: Targeting miRNAs involved in cancer stem cell and EMT regulation: An emerging concept in overcoming drug resistance. Drug Resist Updat 13: 109-118, 2010.

17. Kajiyama H, Shibata K, Terauchi M, Yamashita M, Ino K, Nawa A and Kikkawa F: Chemoresistance to paclitaxel induces epithelial-mesenchymal transition and enhances metastatic potential for epithelial ovarian carcinoma cells. Int J Oncol 31: 277-283, 2007.

18. Lee SG, Kang DC, DeSalle R, Sarkar D and Fisher PB: AEG-1/MTDH/LYRIC, the beginning: Initial cloning, structure, expression profile, and regulation of expression. Adv Cancer Res 120: 1-38, 2013.

19. Emdad L, Das SK, Dasgupta S, Hu B, Sarkar D and Fisher PB: AEG-1/MTDH/LYRIC: Signaling pathways, downstream genes, interacting proteins, and regulation of tumor angiogenesis. Adv Cancer Res 120: 75-111, 2013.

20. Hu G, Chong RA, Yang Q, Wei Y, Blanco MA, Li F, Reiss M, Au JL, Haffty BG and Kang Y: MTDH activation by $8 \mathrm{q} 22$ genomic gain promotes chemoresistance and metastasis of poor-prognosis breast cancer. Cancer Cell 15: 9-20, 2009.

21. Yoo BK, Gredler R, Vozhilla N, Su ZZ, Chen D, Forcier T, Shah K, Saxena U, Hansen U, Fisher PB and Sarkar D: Identification of genes conferring resistance to 5-fluorouracil. Proc Natl Acad Sci USA 106: 12938-12943, 2009.

22. Yoo BK, Chen D, Su ZZ, Gredler R, Yoo J, Shah K, Fisher PB and Sarkar D: Molecular mechanism of chemoresistance by astrocyte elevated gene-1. Cancer Res 70: 3249-3258, 2010.

23. Meng X, Thiel KW and Leslie KK: Drug resistance mediated by AEG-1/MTDH/LYRIC. Adv Cancer Res 120: 135-157, 2013.

24. Zhang J, Zhang Y, Liu S, Zhang Q, Wang Y, Tong L, Chen X, Ji Y, Shang Q, Xu B, et al: Metadherin confers chemoresistance of cervical cancer cells by inducing autophagy and activating ERK/NF-kB pathway. Tumour Biol 34: 2433-2440, 2013.

25. Liu X, Wang D, Liu H, Feng Y, Zhu T, Zhang L, Zhu B and Zhang Y: Knockdown of astrocyte elevated gene-1 (AEG-1) in cervical cancer cells decreases their invasiveness, epithelial to mesenchymal transition, and chemoresistance. Cell Cycle 13: $1702-1707,2014$

26. Ward A, Balwierz A, Zhang JD, Küblbeck M, Pawitan Y, Hielscher T, Wiemann S and Sahin Ö: Re-expression of microRNA-375 reverses both tamoxifen resistance and accompanying EMT-like properties in breast cancer. Oncogene 32 $1173-1182,2013$

27. Zheng J, Li C, Wu X, Liu M, Sun X, Yang Y, Hao M, Sheng S, Sun Y, Zhang H, et al: Huaier polysaccharides suppresses hepatocarcinoma MHCC97-H cell metastasis via inactivation of EMT and AEG-1 pathway. Int J Biol Macromol 64: 106-110, 2014.

28. Schmittgen TD and Livak KJ: Analyzing real-time PCR data by the comparative C(T) method. Nat Protoc 3: 1101-1108, 2008.

29. Yu C, Liu Y, Huang D, Dai Y, Cai G, Sun J, Xu T, Tian Y and Zhang X: TGF- $\beta 1$ mediates epithelial to mesenchymal transition via the TGF- $\beta /$ Smad pathway in squamous cell carcinoma of the head and neck. Oncol Rep 25: 1581-1587, 2011.

30. Yu C, Liu Y, Tan H, Li G, Su Z, Ren S, Zhu G, Tian Y, Qiu Y and Zhang X: Metadherin regulates metastasis of squamous cell carcinoma of the head and neck via AKT signalling pathway-mediated epithelial-mesenchymal transition. Cancer Lett 343: 258-267, 2014

31. Zhang C, Li HZ, Qian BJ, Liu CM, Guo F and Lin MC: MTDH/AEG-1-based DNA vaccine suppresses metastasis and enhances chemosensitivity to paclitaxel in pelvic lymph node metastasis. Biomed Pharmacother 70: 217-226, 2015.

32. Chua MLK, Wee JTS, Hui EP and Chan ATC: Nasopharyngeal carcinoma. Lancet 387: 1012-1024, 2016.

33. Rotin D, Robinson B and Tannock IF: Influence of hypoxia and an acidic environment on the metabolism and viability of cultured cells: Potential implications for cell death in tumors. Cancer Res 46: 2821-2826, 1986.

34. Tannock IF and Rotin D: Acid $\mathrm{pH}$ in tumors and its potential for therapeutic exploitation. Cancer Res 49: 4373-4384, 1989.
35. Yamagata $\mathbf{M}$ and Tannock IF: The chronic administration of drugs that inhibit the regulation of intracellular $\mathrm{pH}$ : In vitro and anti-tumour effects. Br J Cancer 73: 1328-1334, 1996.

36. Vukovic V and Tannock IF: Influence of low $\mathrm{pH}$ on cytotoxicity of paclitaxel, mitoxantrone and topotecan. Br J Cancer 75 : 1167-1172, 1997

37. Huizing MT, Misser VH, Pieters RC, ten Bokkel Huinink WW, Veenhof CH, Vermorken JB, Pinedo HM and Beijnen JH: Taxanes: A new class of antitumor agents. Cancer Invest 13: 381-404, 1995.

38. Gomes LR, Terra LF, Sogayar MC and Labriola L: Epithelial-mesenchymal transition: Implications in cancer progression and metastasis. Curr Pharm Biotechnol 12 $1881-1890,2011$

39. Savagner P: The epithelial-mesenchymal transition (EMT) phenomenon. Ann Oncol 21 (Suppl 7): vii89-vii92, 2010.

40. Lim J and Thiery JP: Epithelial-mesenchymal transitions: Insights from development. Development 139: 3471-3486, 2012.

41. Peppicelli S, Bianchini F, Torre E and Calorini L: Contribution of acidic melanoma cells undergoing epithelial-to-mesenchymal transition to aggressiveness of non-acidic melanoma cells. Clin Exp Metastasis 31: 423-433, 2014.

42. Suzuki A, Maeda T, Baba Y, Shimamura K and Kato Y: Acidic extracellular $\mathrm{pH}$ promotes epithelial mesenchymal transition in Lewis lung carcinoma model. Cancer Cell Int 14: 129, 2014.

43. De Craene B and Berx G: Regulatory networks defining EMT during cancer initiation and progression. Nat Rev Cancer 13: 97-110, 2013

44. Yang AD, Fan F, Camp ER, van Buren G, Liu W, Somcio R, Gray MJ, Cheng H, Hoff PM and Ellis LM: Chronic oxaliplatin resistance induces epithelial-to-mesenchymal transition in colorectal cancer cell lines. Clin Cancer Res 12: 4147-4153, 2006.

45. Shah AN, Summy JM, Zhang J, Park SI, Parikh NU and Gallick GE: Development and characterization of gemcitabine-resistant pancreatic tumor cells. Ann Surg Oncol 14: 3629-3637, 2007

46. Zhang P, Liu H, Xia F, Zhang QW, Zhang YY, Zhao Q, Chao ZH, Jiang ZW and Jiang CC: Epithelial-mesenchymal transition is necessary for acquired resistance to cisplatin and increases the metastatic potential of nasopharyngeal carcinoma cells. Int J Mol Med 33: 151-159, 2014.

47. Zhou Z, Zhang L, Xie B, Wang X, Yang X, Ding N, Zhang J, Liu Q, Tan G, Feng D and Sun LQ: FOXC2 promotes chemoresistance in nasopharyngeal carcinomas via induction of epithelial mesenchymal transition. Cancer Lett 363: 137-145, 2015.

48. Fukumura D, Xu L, Chen Y, Gohongi T, Seed B and Jain RK: Hypoxia and acidosis independently up-regulate vascular endothelial growth factor transcription in brain tumors in vivo. Cancer Res 61: 6020-6024, 2001

49. Shi Q, Abbruzzese JL, Huang S, Fidler IJ, Xiong Q and Xie K: Constitutive and inducible interleukin 8 expression by hypoxia and acidosis renders human pancreatic cancer cells more tumorigenic and metastatic. Clin Cancer Res 5: 3711-3721, 1999.

50. Shi Q, Xiong Q, Le X and Xie K: Regulation of interleukin-8 expression by tumor-associated stress factors. J Interferon Cytokine Res 21: 553-566, 2001.

51. Kato Y, Ozawa S, Tsukuda M, Kubota E, Miyazaki K, St-Pierre Y and Hata R: Acidic extracellular $\mathrm{pH}$ increases calcium influx-triggered phospholipase $\mathrm{D}$ activity along with acidic sphingomyelinase activation to induce matrix metalloproteinase-9 expression in mouse metastatic melanoma. FEBS J 274: 3171-3183, 2007.

52. Hu G, Wei Y and Kang Y: The multifaceted role of MTDH/AEG-1 in cancer progression. Clin Cancer Res 15: 5615-5620, 2009.

53. Yoo BK, Emdad L, Lee SG, Su ZZ, Santhekadur P, Chen D, Gredler R, Fisher PB and Sarkar D: Astrocyte elevated gene-1 (AEG-1): A multifunctional regulator of normal and abnormal physiology. Pharmacol Ther 130: 1-8, 2011.

54. Liu Y, Su Z, Li G, Yu C, Ren S, Huang D, Fan S, Tian Y, Zhang X and Qiu Y: Increased expression of metadherin protein predicts worse disease-free and overall survival in laryngeal squamous cell carcinoma. Int J Cancer 133: 671-679, 2013.

55. Zhu GC, Yu CY, She L, Tan HL, Li G, Ren SL, Su ZW, Wei M, Huang DH, Tian YQ, et al: Metadherin regulation of vascular endothelial growth factor expression is dependent upon the PI3K/Akt pathway in squamous cell carcinoma of the head and neck. Medicine (Baltimore) 94: e502, 2015.

56. Liu H, Song X, Liu C, Xie L, Wei L and Sun R: Knockdown of astrocyte elevated gene-1 inhibits proliferation and enhancing chemo-sensitivity to cisplatin or doxorubicin in neuroblastoma cells. J Exp Clin Cancer Res 28: 19, 2009. 